\title{
The Story of a Dramatic Coup: Overthrowing of the Mossadegh Government in Iran in 1953
}

\section{Süleyman Erkan *}

* Karadeniz Teknik Üniversitesi

E-mail: serkan@ktu.edu.tr

Copyright (C) 2015 Süleyman Erkan. This is an open access article distributed under the Eurasian Academy of Sciences License, which permits unrestricted use, distribution, and reproduction in any medium, provided the original work is properly cited.

\begin{abstract}
Iran was one of the first conflict areas between United States and Soviet Union after World War II. Soviet efforts to settle in Iran was prevented by the determined support of the US and this started close relations with Iran. However problems with UK and Anglo-Iranian Oil Company ( AIOC ) turned into opposition against the West which resulted in the foundation of the National Front under the leadership of Dr. Mohammed Mossadegh. Mossadgh's decision to nationalize Iranian Oil Industry brought Iran and UK to the brink of war. Fearing that a direct military operation would give excuse to the Soviet to intervene, US planned a military coup with UK, in order to topple Mossadegh administration and replace it with a more cooperative goverment. With a coup organized by CIA, Mossadegh was overthrown from power and Army Chief of Staff Zahedi was made Prime Minister. Finally, the use and operation of Iranian Oil was given to a consortium which included American Oil Companies. The coup against Mossadegh, who was popularly elected, brought distrust against the West and US and led to the 1979 Islamic Revolution.
\end{abstract}

Keywords: Coup D’etat, Mossadegh, Iran, Anglo-Iranian Oil Company, Shah, CIA

\section{Dramatik Bir Darbe Hikâyesi: 1953'de İran'da Musaddık Hükümeti’nin Devrilmesi}

\section{ÖZET}

II.Dünya Savaşı'ndan sonra Batı ile Sovyetler Birliği arasında başlayan Soğuk Savaş'ın ilk çatışma alanlarından biri İran olmuştur. Sovyetlerin savaşın ortaya çıkardığı boşluktan yararlanarak İran'a yerleşme çabaları ABD'nin kararlı desteği ile etkisiz kalmış ve iki ülke ilişkilerinde önemli bir yakınlaşma başlamıştır. Ancak, İngiltere / İngiliz-İran Petrol Şirketi ile İran arasında çıkan petrol anlaşmazlığı Batı karşıtı bir harekete dönüşmüş ve Milli Cephe kurularak Dr. Muhammed Musaddık öncülüğünde iktidara gelmiştir. Musaddık'ın İran petrollerini millileştirme kararı alması ve bunun parlamento tarafından da onaylanması İngiltere ile İran'ı bir savaşın eşiğine getirmiştir. İran'a bir askeri müdahalenin Sovyetleri de işin içine sokacağından çekinen ABD İngiltere ile birlikte Musaddık Hükümeti'ni organize bir darbeyle devirmeyi ve kendileriyle işbirliği yapacak yeni bir hükümeti işbaşına getirmeyi daha uygun görmüştür. CIA tarafından organize edilen darbe sonucunda Musaddık devrilerek Genel Kurmay Başkanı Zahedi başbakan yapılmış ve İran petrollerinin işletim hakkı aralarında ABD Şirketlerinin de olduğu bir şirketler konsorsiyumuna verilmiştir. Halk tarafından seçilen 
Musaddık'ın devrilmesi Batı'ya ve ABD' ne olan güveni sarsmış ve 1979 İslâm Devrimi’nin ortaya çıkmasının yolunu açmıştır.

Anahtar Kelimeler: Darbe, Musaddık, İran, İngiliz-İran Petrol Şirketi, Şah, CIA

\section{1-Giriş}

Radikal iktidar değişiklikleri ülkelerin dış politikalarında çoğu zaman derin kırılmaların yaşanmasına yol açmıştır. Bu ani ve beklenmedik iktidar değişiklikleri askeri darbeler sonucunda meydana gelmişse sonuçları ve etkileri çok daha derin olmaktadır. Darbeler çoğunlukla bir ülkede ordu tarafından hükümetlerin anayasal olmayan eylemlerle devrilmesidir. ( Luttwark, 1980: 170 ) Demokrasi kültürü zayıf ancak stratejik bakımdan önemli ülkeler askeri darbelerle daha çok karşılaşırlar. Böyle ülkelerde darbeler iç politikadaki sorunlardan ve anlaşmazlıklardan kaynaklansa bile diş ülkelerin müdahale ve destekleri ile gerçekleşirler. Dışarıdan destek gören darbe yönetimleri iktidarı ele geçirdiklerinde kendilerini destekleyen ülkelerle uyumlu bir dış politika izlemek zorundadırlar.

Darbe geleneğinin en yaygın olduğu bölgelerden biri de Orta Doğudur. Orta Doğu'da askeri darbe ile yolu kesişmemiş ülke neredeyse yok gibidir. Bölgede en çok darbe ya da darbe girişimi ile karşılaşan ülkeler arasında Suriye, Irak, Yemen, İran ve Mısır yer almaktadır. Suriye'de 1950 li yılların başında kısa aralıklarla meydana gelen darbeler günümüze kadar sürecek olan Baas Partisi iktidarlarının önünü açarken bu parti iktidarları döneminde de zaman zaman parti içi çekişmeler yüzünden yeni darbeler eksik olmamıştır. Yemende günümüzde yaşanan iç savaş ve siyasi istikrarsızlıkların nedeni de darbeler ile iç içe yaşayan bir ülke olmasıdır. 1958 yılında ordunun Genelkurmay Başkanı Abdülkerim Kasım önderliğinde gerçekleştirmiş olduğu askeri darbe sonunda Irak Batı ile ilişkilerini koparıp Sovyetler Birliğine yaklaşmıştır. Suriye'de olduğu gibi Irakta da sonraki yıllarda Baas Partisinin siyasette dominant hale gelmesi bu darbenin etkisiyle olmuştur. Bununla birlikte gerek iç politikada gerekse diş politikada askeri darbelerin en çok etkilediği ülkeler İran ve Mısırdır. Bu ülkeler aynı zamanda Orta Doğu politikasında en önemli aktörlerdir.

İran 20.Yüzyılda Orta Doğu Bölgesi'ndeki tek bağımsız ülkeydi. Birinci Dünya Savaşı öncesi İngiltere ile Rusya arasında nüfuz bölgelerine ayrılmış olan İran savaştan sonra ise Sovyet-İngiliz rekabetine konu olmuştur. İran'da ilk askeri darbe 1921 yılında gerçekleşmiştir. Ahmet Şah'a bağlı Kazak Tugayları Komutanı olan Ahmet Rıza Han Müşir al-Dawleh liderliğindeki hükümeti devirerek Başbakanlığa Sayed Ziya'yı getirirken kendisi de Harbiye Bakanı olmuştur. 1923'de ise ikinci bir darbe ile Sayed Ziya'yı da devirerek başbakanlığ üstlenmiştir. 1925 yılında da Şah Ahmet'i tahttan indirerek Kaçar Hanedanlığına son vermiş ve kendisini İran Şahı ilan etmiştir. Oysa herkes İran'da Cumhuriyet ilan edileceği beklentisi içerisinde idi. ( Martin, 1994: 199-210 ) 20.Yüzyılda İran'da ikinci önemli darbe 1953 yılında gerçekleşti. Soğuk Savaş Döneminin Uluslararası Politika dinamiklerinin rol oynadığı darbenin İran'ın iç ve politikasında geniş etkileri uzun sürmüş ve pek çok tartışmalara konu olmuştur. Amerika ve İngiltere'nin seçimle işbaşına gelmiş olan Dr. Muhammed Musaddık Hükümeti'nin devrilmesindeki rolleri yoğun eleştirilere yol açmıştır. 
1953 askeri darbesi ABD ve Batı Bloku'nun Orta Doğu Bölgesinde demokratik Gruplar yerine otoriter ve diktatör kesimlerle işbirliği yapmakta hiçbir sakınca görmediklerinin garipsenecek örneklerinden biridir. Bundan daha da şaşırtıcı olanı darbelerin gerçekleşmesinde fiili olarak yer alınmasıdır. 1953 darbesi İran'daki siyasi gruplar arasındaki bir rekabetin sonucunda değil CIA nın bizzat yer aldığı ve sonucu belirlediği bir olaydır. Nitekim CIA 2013 yılında bu darbede aktif olarak yer aldığını itiraf ederek tüm belgeleri yayımlamıştır. İngiltere'de 19 Ağustos 2013 tarihinde (Darbenin 60. Y111 ) Guardian Gazetesi bu itirafı “CIA admits role in 1953 Iranian Coup- CIA 1953 Darbesindeki Rolünü İtiraf ediyor " manşetiyle vermiştir. ABD'nin saygın Üniversitelerinden biri olan George Washington Üniversitesi bünyesinde bulunan National Security Archive, bu darbe ile ilgili tüm belgelerin yer aldığ1 elektronik bir brifing kitabı yayınlamıştır. ( "The Secret CIA History of the Coup, 1953 -1953 Darbesinde CIA nın Gizli Hikayesi “, National Security Archive, Electronic Briefing Book No. 28.) Günümüzde de Amerika-İran ilişkileriyle ilgilenen diplomat, gazeteci ve akademisyenlerin tamamına yakını ABD’nin darbedeki rolünü eleştirmekte ve bunu en büyük dış politika yanlışlarından biri olarak sunmaktadırlar. Profesor Stephen Kinzer ise, bu belgeler 1şığında darbeyi hikayemsi bir anlatımla, “Şah’ın Bütün Adamları “ adlı kitabında ele almıştır.

Bu makalede 1953 darbesine giden süreç analiz edilerek, darbeyi ortaya çıkaran faktörlere yer verilecektir. Darbenin Soğuk Savaş yıllarındaki anlamı ile İran Siyasal hayatında, dış politikasında ve özellikle ABD-İran ilişkilerinde yarattığı travma ele alınacaktır.

\section{2-Soğuk Savaş'ın Başlangıcında İran}

İran II. Dünya Savaşından sonra ABD ile Sovyetler Birliği arasındaki ilk ve en önemli çatışma alanlarından birisi olmuştur. Savaştan önce İran'daki Şah Ahmet Rıza Yönetimi Almanya ile birlikte diğer Mihver Devletlerine sempati duymakla birlikte resmen tarafsız olduğunu deklere etmiş ve savaş dişında kalmıştı. Ancak Nazi Almanya'sının Sovyetler Birliği'ne saldırmasıyla ABD, İngiltere ve Sovyetler savaşta aynı cephede buluştular. ABD ve İngiltere Sovyetlere yardım kararı aldılar. Fakat Sovyetlere bu yardımı ulaştırabilecekleri bir güzergah yoktu. Baltık deniz yolu Almanya'nın kontrolü altında bulunuyordu. Türk Boğazlarından Sovyetlere yardım da Montreux engeline takılıyordu. Çünkü Montreux Sözleşmesine göre, ( madde, 19 ) savaş zamanında boğazlar tüm ülkelerin savaş gemilerine kapalı tutulacaktı. İran Sovyetlere yardım için tek alternatif geçiş koridoruydu. Fakat yukarıda da belirtildiği gibi, Ahmet Rıza Şah hem tarafsızlığını ilan etmiş hem de zaten Nazi Almanya'sı ile birlikte diğer Miğfer Devletlerine sempati duyuyordu. İran'ın tarafsızlığına aldırış etmeyen Müttefik Devletler ( ABD, İngiltere, SSCB ) 1941 yılında İran'ı işgal ettiler. ( Erkan, The Invasion of Iran, 2010: 112 ) Şah Ahmet'i ülkeden sürgün ederek yerine genç yaştaki oğlu Muhammed Rıza Pehlevi’yi getirdiler. İşgalin İran'da ve dünyada yaratacağı olumsuz etkiyi ortadan kaldırmak için İranla 1942 yılında bir anlaşma imzalayarak savaşın bitmesinden sonra en geç altı ay içerisinde askerlerini İran topraklarından çekeceklerini kabul ettiler. Bu çekilme konusu 1943 yılında Müttefik Devletlerin buluştuğu Tahran Konferansında da tekrarlandı. ( Hamzavi, 1944: 195-198 ) 
Batılı ülkelerle Sovyetler arasındaki işbirliği savaş süresince oluşan bir zorunluluk ilişkisiydi. Varoluş nedenleri birbirlerini yok etmek olan Kapitalizm ile Komünizmin temsilcilerinin savaşın sona ermesiyle er ya da geç çatışacakları kaçınılmazdı. Nitekim 1945 yılında savaş sona erince İran'dan çekilme konusu Batılı ülkelerle Sovyetleri karşı karşıya getirdi. ABD ve İngiltere İran'dan askerlerini çekerken Sovyetler savaş sonrası konjektürden yararlanarak İran'dan askerlerini çekmeye yanaşmadı ve İran'ı boşaltmadığı gibi ülkedeki etnik gruplara destek vererek İran'1 parçalamaya çalıştı. İngiltere'nin I. Dünya Savaşından sonra İran'a tek başına hakim olmaya çalışması gibi, Sovyetler de II. Dünya Savaşından sonra Batılıların askerlerini çekmesini firsat bilerek İran'a yerleşmeye karar verdi. Sovyetleri İran'dan çıkaracak gücü olmayan İran'daki Ahmet Qavam Hükümeti çatışma yerine onlarla anlaşma yolunu seçti. 1946'da imzalanan bir anlaşmaya göre, Sovyetler İran'dan çekilmenin karşılığında Kuzey İran bölgesindeki petrollerin işletilmesinden \%51 pay alacaklardı. Ancak bu anlaşmanın İran Parlamentosu tarafından onaylanması gerekiyordu. Anlaşma Parlamentoya geldiğinde ABD devreye girerek anlaşmanın onaylanmaması yönünde İran'a açık destek verdi. ABD nin desteğinden cesaret alan İran Parlamentosu da neredeyse oybirliği ile anlaşmayı onaylamayı reddetti. ( Lenczovski, 1972: 45-55, Hess, 1974: 123 ) Soğuk Savaşın başlarında İran üzerindeki rekabetin ilk ayağını Sovyetler kaybederken sınırında yer alan ve jeopolitik açıdan çok önemli olan İran'a Batılıların yerleşmesinden hiç memnun olmamıştı.

\section{3-ABD'nin İran'da Etkin Hale Gelmesi}

ABD’nin Sovyetlere karşı İran'a verdiği bu açık desteğin iki ülke ilişkilerinde pozitif yansımaları oldu. İran'a verilen desteğin en önemli aktörlerinin başında ABD’nin Tahran Büyükelçisi George V. Allen geliyordu. ABD İran'1 Sovyet işgalinden kurtaran ve parçalanmasını önleyen ülke olarak İran Kamuoyunda ve siyasi çevrelerinde son derece saygın bir prestij kazanmıştı. İran'ın geçmişte Rusya ve İngiltere ile önemli anlaşmazlıkları olmasına rağmen $\mathrm{ABD}$ ile herhangi bir sorun yaşamamıştı. Bu kamuoyu algısı ABD'nin İran'la ilişkilerini geliştirmesi için önemli kolaylıklar sağlıyordu. Özellikle Şah Muhammed Rıza Pehlevi Yönetimi Sovyetlerle yaşanan krizden sonra ABD’ne büyük bir güven duymaktaydı. Şah ve Hükümet çevrelerinde pek çok ABD li danışman yer alıyordu. ( Axworty, 2008: 234 ) Savaş sonrası ülkenin sosyoekonomik problemlerinin çözümünde de ABD yardımından medet umulmaktaydi.

ABD’nin İran'daki etkinliği özellikle 1947 yılından itibaren artmaya başladı. İki ülke arasında imzalanan bir askeri eğitim anlaşmasıyla İran jandarma birliklerinin eğitim ve donatımı ABD tarafında sağlanacaktı. ABD bu programın finansmanı için İran'a 60 milyon dolarlık bir yardım yapacaktı. Programın yürütülmesinin sorumluluğu ABD li Albay Schwarzkopf’a verilmişti. ( Keddie, 2003: 114 ) Başta Azeri Bölgesi Tebriz ve Kürt Bölgesi Mahabad olmak üzere, ülkenin değişik bölgelerindeki merkezi yönetime karşı ayaklanmaların bastırılmasında bu programın etkisi küçümsenemeyecek kadar önemliydi. Ekonomik sorunların aşılmasında da ABD'den beklentiler büyüktü. İran Parlamentosunda çoğunluk toprak sahibi feodallerin elindeydi. Bu nedenle ABD Parlamento ve Hükümet Üyeleri ile kolay iletişim 
kurabiliyordu. Nitekim İran Hükümetinin daveti üzerine, Ağustos 1947'de, ABD Mühendislik Firması Morrison-Knudson İran'a davet edilerek bir kalkınma programı hazırlandı. Plan tarımsal teknoloji ve küçük sanayinin geliştirilmesine öncelik vermekteydi. Programda ham pamuk ve yün üretiminin de artırılması öngörülüyordu. Plana İran'1 Batı'nın hammadde kaynağı yapmayı öngörmesi nedeniyle bazı itirazlar olmuşsa da bundan vazgeçilmedi ve aynı yıl bir plan komisyonu kuruldu. Komisyon tarafından hazırlanan ve Yedi Y1llık Plan adı verilen program 1948 yılında Parlamentoya sunulmuş ve kabul edilmişti. Planın yürütülmesinde ABD geniş bir role sahipti. Max W. Thornburg planın danışman ve icra direktörü olarak çok geniş yetkiye sahipti. ( Keddie, 121 )

ABD'nin katkılarıyla hazırlanan Kalkınma Planının İran'ın ekonomik sorunlarına kısa sürede çözüm getirmesi mümkün değildi. Başlangıçta halk ve politik çevreler ABD'nin İran'a yardımına sıcak baksalar da, kısa sürede bir muhalefetin ortaya çıkması gecikmedi. Ekonomik durumu iyi olmayan halk, Batı'nın İran'la ilgilenmesini sahip olduğu kaynakları ve özellikle petrolü sömürmeye yönelik olduğu gerekçesiyle eleştirmeye başladı. İran basınında bu eleştirilerin geniş yer bulması muhalefetin oluşmasında önemli rol oynadı. İran Komünist Partisi TUDEH İran'ın sömürülmesinde yeni öncü ülkenin ABD olduğu algısını yaymaya başladı. 1949 yılında Şaha bir suikast girişiminde bulunulması üzerine Komünist Parti yasa dışı ilan edildiği gibi ülkede basına da önemli yasaklar getirildi. (Cottam, 1970: 9 ) Ancak ABD’nin İran'da karşılaştı̆ğ muhalefet bu olaylardan çok İngiltere'nin İran petrollerini işletme hakkını elinde bulunduran Anglo Iranian Oil Company ( AIOC ) ile yaşanan anlaşmazlık oldu.

\section{4-İngiltere-İran Petrol Krizinin Ortaya Çıkması}

İran'ın Batı ile ilişkilerinin bozulmasının temelinde AIOC nun faaliyetleri önemli bir yer tutmaktadır. Bu şirket, 1914 yılında, daha sonra İngiltere'de Sir ünvanı verilecek olan Arnold Wilson'un genel sekreterliğinde kuruldu. Kurulduğunda adı Anglo-Persian Oil Company olmasına rağmen, 1917'de, Anglo Iranian Oil Company olarak değiştirilmişti. Şirket İran petrollerinin üretim ve satış tekelini elinde bulunduruyordu. Başlangıçta İran'a ürettiği petrolden sadece \% 16 oranında pay vermesi nedeniyle ülkedeki nasyonalist, muhafazakar ve marxist çevrelerin hedefi haline gelmişti. ( Katouzian, 1979: 514 , Erkan, İran'a Yabancı Ülke Müdahaleleri: 109 ) İngiltere'nin İran'la 1919 yılında imzaladığı ve adeta ülkeyi bir sömürge haline getiren anlaşmanın Parlamento tarafından reddedilmesi ve 1921 Anlaşmasıyla Sovyetlerle yakınlaşılmasına rağmen şirket petroller üzerindeki tekelini sürdürdü. Petrollerin üretim ve satışıyla ilgili son anlaşma 1933'de imzalandı. ( Armaoğlu, 1999: 489)

II. Dünya Savaşından sonra ABD ile İngiltere'nin Sovyetlerle İran'da girdikleri mücadelede bu ülke petrollerine sahip olmak önemli bir yer tutuyordu. İngiltere ABD ile birlikte Sovyetleri İran'dan çıkarma başarısı göstermenin rahatlı̆̆ı ile AIOC nın petroller üzerindeki üretim hakkının neredeyse ebedi olduğuna inanmaya başladı. İranda etkisi her geçen gün artan $\mathrm{ABD}$ çevreleri bile bundan oldukça rahatsızdılar. ABD petrol şirketleri Suudi Arabistan, Nijerya, Endonezya gibi ülkelerde üretilen petrollerden bu ülkelere yarı yarıya ( $\%$ 50 ) pay verirken İngiltere İran'a verdiği payı neredeyse \% 20 lerde tutuyor ve bunu da eski 
anlaşmalara dayandırıyordu. 1945 yılında, şirketin İran petrollerinden elde etmiş olduğu gelirden İngiltere Hükümetine 5.055.000 sterling verilirken bu rakam 1948'de 31.685.000'e çıkmıştı. İran Hükümeti'nin petrol gelirlerinden elde ettiği pay ise sadece 9.172 .000 sterling kadardı. ( Paine and Schoenberger, 1975: 14 ) Şirketin İran'a ödediği payın uluslararası standartlarla aşırı farklılık göstermesi ve bunu artırmaya yaklaşmaması İran'ın Batı ve özellikle İngiltere ile ilişskilerini zehirleyen en önemli anlaşmazlık konusu oldu. İran muhalefeti şirket üzerinden Şah'a ve Hükümete karşı hücuma geçti ve ülkede nasyonalist eğilim tavan yaptı.

İran'da halk arasında ülkenin ekonomik sorunlarının çözülememesinin nedeninin petrolden yeterince gelir elde edilememesi olduğuna dair inanç her geçen gün derinleşti. Yaklaşık 19 milyon nüfusun sadece \%15'i şehirlerde geri kalanı ise köylerde yaşamaktaydı. Ancak köylerde yaşayan nüfusun \%60'ının toprağı yoktu. Toprağın işlenmesi ve tohumculukta son derece ilkel şartlarda yapılmakta idi. Bununla birlikte okuryazarlık toplumun her katmanında oldukça yaygındı. Bu durum AIOC üzerinden İngiltere ve hatta ABD'ne olan nefreti besliyordu. ( Keddie, 2003: 124 ) Yoksul kesime göre, ülkenin geri kalmasının nedeni İran Hükümetinin ülkenin en önemli gelir kaynağı olan petrolü neredeyse bedavaya yabanc1 ülkelere vermesiydi. Her ne kadar Hükümet 1949 yılında muhalefetin baskısı üzerine İngiltere ve AIOC ile yeniden masaya oturarak 1933 Anlaşmasına ek bir anlaşmaya varmışsa da bu halkı memnun edecek düzeyde değildi. Anlaşma İran'a petrolden verilen payı biraz daha artırıyordu. Ancak bu anlaşmanın yürürlüğe girmesi Parlamento tarafından onaylanmasına bağlıydı. ${ }^{1}$ Parlamento Aralık 1949'da anlaşmayı onaylamayı reddetti. Anlaşmanın reddedilmesinde baş rolü İran Parlamentosundaki Muhalefet kanadı Milli Cephenin lideri Dr.Muhammed Musaddık oynamıştı. ${ }^{2}$

Musaddık'ın önderliğinde Parlamentoda oluşan Milli Cephe'nin yanı sıra Molla Kaşani liderliğindeki fanatik şii kanat ve yasa dışı ilan edilen Komünist Parti TUDEH de petroller konusunda AIOC 'a hiçbir şekilde taviz verilmemesinde 1srar etmeye başladılar. Her ne kadar AIOC geri adım atarak petrol gelirinden uluslararası standartlara uygun olarak İran'a vereceği pay1 \%50 ye yükseltmeyi kabul etmişse de, Parlamentoda Musaddık ve muhalif milletvekilleri buna yanaşmayarak İran petrollerinin devletleştirilmesini ortaya attılar. ( Gasiorowski, 1987: 262 ) Musaddık'ın bu önerisi gerek parlamentoda gerekse parlamento dışında yoğun ilgi gördü.

\footnotetext{
${ }^{1}$ İran Parlamentosu tarihinde hükümetlerin yabancı ülkelerle imzaladıkları ve onlara ödünler veren anlaşmaları onaylamama konusunda önemli bir şöhreti vardır. 1919 'da imzalanan İngiltere-İran Anlaşmasını İran Parlamentosu 1921'de onaylamayı reddetmişti. Bkz. Erkan, İran’a Yabancı Ülke Müdahaleleri,...p.107. Yine yukarıda belirtildiği gibi, 1946'da Sovyetlerle imzalanan anlaşma da İran Parlamentosu tarafından onaylanmamıştı. Böylece 1949 Anlaşmasının reddedilmesi de bu geleneğin devamını göstermekteydi. Reddedilen her üç anlaşmanın ortak paydasını da İran petrolleri oluşturmaktaydı.

21882 yılında Tahran'da doğan Muhammet Musaddık İran dışında doktora yapan ilk hukukçudur. Fransa ve Belçika'daki üniversitelerde bulunmuş ve doktora derecesini İsviçrenin Lozan Üniversitesinden almıştır. 1919 yılında İran Hükümetinde Adalet Bakanlığg görevinde bulunmuştur. 1925 yılına kadar Parlamento'da milletvekili olarak görev yapmış ancak Şah Ahmet Rıza’nın gerçekleştirdiği darbeden sonra istifa etmişstir. 1944 yılında yapılan seçimlerde yeniden milletvekili olarak parlamentoya dönmüştür. Bkz., Axworthy, p. 235.
} 
Parlamento'da üç kişiyle başlayan Milli Cephe'ye destek çı̆̆ gibi artarken parlamento dışında halk gösterileri yaygınlaşmaya başladı. Olay bir yabancı düşmanlığı şeklinde kitlesel bir harekete dönüşmeye başlamıştı. Parlamento'nun petrol imtiyaz anlaşmasını reddetmesi aynı zamanda anlaşmayı imzalayan Hükümete karşı bir güvensizlik anlamına geliyordu. Şah Muhammed Rıza Pehlevi de anlaşmanın reddedilmesi nedeniyle zor durumda kalmış ve bunu hükümetin beceriksizliğine bağlamıştı.

Şah bu durum karşısında, 1948 den beri başbakan olan ve AIOC ile reddedilen anlaşmayı gerçekleştiren Demokratik Partili Muhammed Said'i görevden alarak, hükümeti kurma görevini Diriliş Partisinden Ali Mansur'a verdi. Böylece, anlaşmanın ülkede yarattığı krizin sorumluluğu hükümete mal edilmiş oldu. AIOC de \%50 konusunda ikna olduğuna göre, yeni hükümet hem İran'ın çıkralarını koruyacak hem de Batılı ülkelerle ilişkilere zarar vermeyecek bir anlaşma gerçekleştirebilirdi. Ancak Ali Mansur ismi gerek Parlamentoda gerekse kamuoyunda şaşkınlık yarattı. Daha önce adı

yolsuzluklarla anılan bir kişinin başbakan olması hükümete karşı muhalefetin daha da artmasına yol açtı. Kısa süre içerisinde Ali Mansur'un İran'1 krizden çıkaramayacağına dair alg1 kuvvetlendi. Saray Yönetimi de ondan umudunu kesmişti. Ancak Şah yine de onu görevden alma konusunda isteksizdi. Fakat Kore Savaşı'nın çıkmasından sonra ABD, İngiltere ve bir kısım halkın isteği üzerine onu görevden almak zorunda kaldı. Başbakanlığı sadece üç ay sürmüştü. ( Abrahamian, 2008: 174 ) Anlaşmanın ret edilmesinden beri AOIC ile ilişkilerde bir belirsizlik ortaya çıkmıştı. Yeni Hükümet hem bu belirsizliğe çare üretmek hem de İran'1 bir kaostan çıkaracak bir misyona sahip olmalıydı.

\section{5-Ali Razmara'nın Başbakanlığı ve Krizin Tırmanması}

Başbakan Ali Mansur'un görevden alınmasından sonra yeni hükümeti kimin kuracağ1 önem kazandı. Yeni başbakanın öncelikle hükümeti kurma görevini alacağı Şah Muhammed Rıza ile arasının iyi olması gerekiyordu. İngiltere ile yaşanan petrol krizini çözecek ve muhalefete yönelik halk desteğini kendi tarafına çekebilme becerisine sahip olmalıydı. Ayrıca Sovyetlerle de ilişkileri yumuşatabilirse TUDEH'in saldırılarını da savuşturabilirdi. Tüm kesimleri memnun edecek bir sihirli formül bulmak zor olacağından yeni hükümet klasik söylemle adeta ateşten gömlek giymiş olacaktı. Ancak yeni başbakanın İran Petrollerinin millileştirilmesi taraftarı olmaması atanması için öncelikli kriter sayıldı ve görev ordu kökenli General Ali Razmara'ya verildi.

Razmara'nın Başbakanlığa atanmasında İran'ın Güneyindeki petrollerin bulunduğu bölgede etkin olan Feodal Aşiret Liderlerinden Nasır Khan Qashqai'nin Şah'a tavsiyesi etkili oldu. İngilizlerle de görüşen Qashqai Razmara'nın başbakanlığını desteklemelerini istedi. Qashqaiye göre, Razmara hem önemli bir askeri kariyere sahipti hem de feodal kabileler üzerinde büyük etkisi vardı. Bundan daha da önemlisi petrolün millileştirilmesini isteyen cepheyle herhangi bir bağlantısı yoktu. ( Ghods, 1993: 24-25 ) Şahın Razmara’yı Başbakanlığa 
getirmesinde İngiltere'nin yanı sıra ABD arzusu da etkili oldu. Bununla birlikte Şah Razmara'yı geniş yetkilerle donatma taraftarı değildi. Hükümeti kurma görevini verirken, ondan bakanların sivil nitelikli olmasını ve ordudan uzak durmasını istemişti. Razmara'nın göreve başladığı gün ordudaki en önemli rakibi General Zahidi'yi polis kuvvetlerinin başına getirmesi onu kontrol altında tutmak istediğinin bir göstergesiydi. Şah ayrıca Razmara'dan, İran'ın sürgündeki karizmatik dini liderlerinden olan Ayetullah Ebulkasım Kaşhani’nin sürgünden dönmesine izin verilmesini de istemişti. ( Kinzer, 2004: 114 )

Razmara Hükümeti'nin kuruluşu $A B D$ ve İngiltere tarafından hoş karşılansa da muhalefet ve Milli Cephe tarafından ilk günden itibaren hedef haline getirildi. Her ne kadar Hükümet Programında, ülkenin tamamında güvenlik ve sükunetin sağlanacağı, vilayetlerde meclisler kurulacağı, halkın ve köylülerin yaşam şartlarının iyileştirileceği ve Sovyetlerle 1946'dan beri kesilen ticari ilişkilerin yeniden başlatılacağı ve İran'ın tarafsız bir ülke olacağı gibi ifadelere yer verilmişse de, Milli Cephe lideri Musaddık bunları ciddiye almamış ve ona karşı tüm gücüyle muhalefetini sürdüreceğini açıklamıştı. Musaddık’a göre, Razmara Hükümeti adeta yarı bir darbe ile işbaşına gelmişti. Milli Cephenin önde gelen diğer isimlerinden biri olan Muzaffer Baghai ise, daha da ileri giderek, Razmara'yı Hitlere benzetmişti. İngiltere Razmara Hükümeti'ni AIOC ile istediği bir anlaşmayı imzalayacak ve onu parlamentoda kabul ettirecek bir oluşum olarak gördü. ABD ise Razmara Hükümeti'nin desteklenmesini daha geniş bir perspektiften ele aldı. Kore Savaşı çıkalı bir hafta olmuştu. New York Times Gazetesinde Albion Ross yazdığı bir makalede, Kore Savaşı nedeniyle İran'ın stratejik öneminin daha da arttığına dikkat çekerek, ABD’nin Şah ve atadığı Razmara Hükümeti'nin desteklenmesine vurgu yapmıştı. ( New York Times, June 28: 1950 , Ghods, 1993: 26 )

ABD, Razmara Hükümetini AIOC ile İran arasında yaşanan petrol anlaşmazlığının çözülmesi için bir şans olarak görüyordu. Dışişleri Bakanı Dean Acheson'un yardımcısı $\mathrm{McGhee}^{3}$, bu anlaşmazlığın çözümü için AIOC 'nin bir takım ödünler vererek Parlamento'dan geçecek bir anlaşma için Başbakan Razmara'ya yardımcı olmaları gerektiğini şirket yöneticilerine söylediğinde, yetkililer şirketin yeterince kar etmediğini ve bu ödünleri veremeyeceklerini belirttiler. Oysa McGhee, yaptırdığ 1 bir araştırma ile hazırlanan raporda, şirketin olağanüstü kâr elde ettiğini ve çıkarttığı petrolün üretim maliyetinin on ile otuz kat arasında bir ücretle sattığını görmüştü. İran'da halkın AIOC ve İngiltere'den nefret etmesinin en önemli nedeninin şirketin bu tutumundan kaynaklandığ 1 bütün çıplaklığ1 ile ortada idi. Bunun bir felakete dönüşeceği ve şirketin bu davranışı nedeniyle Batı'nın büyük bir stratejik öneme sahip İran'daki çıkarlarının zarar göreceği endişesiyle, Eylül 1950'de ( Razmara

\footnotetext{
${ }^{3}$ ABD Dışişleri Bakanı Dean Acheson tarafından Yakın Doğu, Güney Asya ve Afrika işlerinden sorumlu bakan yardımcılığına atanan George McGhee liberal düşünceye sahip bir Teksaslıydı. Oklahoma Üniversitesi’nde Jeoloji okumuş ve daha sonra Rodos bursu kazanarak Oxford'a gitmişti. Oxford'daki çalışmalarını bitirdiğinde AIOC kendisine İran'da mühendis olarak çalışma önerisinde bulunmuş ancak o bunu kabul etmemişti. ABD'ne dönen McGhee kendi şirketini kurmuş ve çok büyük başarılar kazanmıştı. Kısaca, McGhee hem petrol hem de AIOC nin faaliyetleri konusunda oldukça uzman bir kişiydi. ( Bkz. Kinzer, 2004: 112 )
} 
Hükümeti'nin kurulmasından iki ay sonra ) Londra'yı ziyaret etti ve gerek hükümet gerekse şirket yetkilileriyle görüşmelerde bulundu. ( Kinzer, 2004: 114 )

Londra görüşmelerinde McGhee, ne hükümet ne de şirket yetkililerini İran'a ödün verme konusunda ikna edemedi. İkna etmek bir yana Londra'da oldukça soğuk bir şekilde karşılanmıştı. ABD ile İngiltere arasında kriz konusunda derin bir yaklaşım farkı oluşmuştu. Bu yaklaşım farkı Tahran'daki iki ülkenin büyükelçilerinin tutumunda da oldukça belirgindi. Her iki ülke de krizin derinleştiği 1950 y1lında Tahran'a yeni büyükelçiler göndermişlerdi. ABD’nin yeni Tahran Büyükelçisi Henry Grady, Birleşik Devletlerin gelişen dünyadaki milliyetçi güçlerle işbirliği yapmaması durumunda bu güçlerin Marksizme ve Sovyetler Birliğine yaklaşacağına inanıyordu. Yani ABD İran'da da Milli Cepheyi karşısına almamalı ve onunla yakınlaşmalıydı. Oysa İngiltere'nin Tahran Büyükelçisi Sir Francis Shepherd ABD elçisiyle İran'da, yaşanmakta olan olaylar konusunda, tamamen ters kutupta yer alıyordu. Nitekim iki ülke büyükelçilerinin kriz konusunda ülkelerine gönderdikleri raporlarda bu durum açıkça görülmektedir. ( Kinzer, 2004: 114 ) ABD, AIOC ile İran arasında yaşanmakta olan krizin kendisinin bu ülkedeki kazanımlarını tehlikeye attığının farkında idi. Razmara Hükümeti'nin kurulmasından sonra, ABD'nin İran'a yönelik ilgisi daha da artmıştı. Truman Yönetimi, İran'ın ana eksenini petrol anlaşmazlığının oluşturduğu bölünme nedeniyle, ikinci bir Çin olmasından büyük bir endişe duyuyordu. ${ }^{4} \mathrm{Bu}$ nedenle, İran'a yönelik yeni bir yardım programı devreye konularak, Razmara Hükümetiyle bir anlaşma imzalandı. Anlaşmada, İran’a her yıl 23 milyon dolar askeri yardım yapılacaktı. Ayrıca İthalat ve İhracat Bankası aracılığı ile 25 milyon dolar, Uluslararası Banka aracılığı ile de 10 milyon dolar olmak üzere toplam 35 milyon dolarlık mali destek sağlanacaktı. ( Gasiorowski, 1978: 267 ) Fakat şirketin ve İngiltere'nin geri adım atmaması bu yardım programını önemsiz hale getirdi.

ABD ile İngiltere arasında kriz konusunda beliren ayrılık, Milli Cephe'yi ve ona destek veren diğer muhalefet gruplarını, daha da cesaretlendirdi. Musaddık'a olan milliyetçi kesimin desteği her geçen gün artmaya başladı. ( Efimenco, 1955: 396 ) Milli Cephe ile organik bir bağ1 olmamasına rağmen, TUDEH ideolojik nedenlerle krizin tırmanması için daha aktif hale geldi. 1949'da, Şah'a karşı girişilen suikasttan sonra, kendisini fesheden ve yer altına çekilen TUDEH, Razmara Hükümeti'nin kurulmasından biraz önce yarı legal hale gelmiş fakat pek çok yöneticisi tutuklanmış ya da kaçmıştı. ( Behrooz, 2001: 366 ) Bu operasyondan sonra partinin genel sekreteri Comrade İskandari'nin yerine Kianuri gelmiş ve Milli Cephe Lideri Musaddık'a TUDEH açıktan destek vermeye başlamıştı. ( Halliday, 1980: 21 ) Milli Cephe'yi Parlamento dışında bir başka güçlü destek ise Kaşhani'nin milis kuvvetlerinden gelmişti. Nitekim Razmara Başbakan olarak atandığı gün Kaşhani yaptığı açıklamada, “ Yıllardır İran bir diktatörün yönetimi altındaydı. Şimdi yeni bir diktatör geldi. Bu hükümet yabancılara hizmet için geldi ve bütün İran Halkı buna karşı çıkmalı “ diyerek, Razmara Hükümetine karşı açıktan savaş ilân etmişti. ( Ghods, 1993: 26 ) Bu desteğin etkisiyle Musaddık İran Parlamentosu'na ülke

\footnotetext{
${ }^{4}$ Çin'de 1946'da iç savaşın çıkması sonucu 1949'da ABD karşıtı Komünist bir rejim işbaşına gelmiş ve bölgedeki çok önemli bir ülke elden kaçırılmış, Batı'nın çıkarları büyük yara aldığı gibi bölgenin güvenliği de tehlikeye girmişti.
} 
petrollerinin millileştirilmesi için bir yasa tasarısı sundu. Böylece İngiltere-AIOC, Hükümet ve Milli Cephe arasındaki kriz doruk noktasına ulaştı.

Milli Cephenin İran petrollerinin millileştirilmesi tasarısını Şubat 1951'de parlamentoya sunması, İran Kamuoyunda büyük bir heyecan yarattı. Gelişmelerin nasıl sonuçlanacağı hususunda Sovyetler de büyük bir merak içerisindeydi. ABD olup bitenlerin İngiltere ve AIOC nin inadı yüzünden çıkmaza doğru sürüklendiği için kızgın olsa da, bunu Soğuk Savaş’ın dengeleri yüzünden açığa vurmuyor, bir çözüm bulunacağı ümidini koruyordu. Tasarı karşısında asıl önemli olan Razmara Hükümeti'nin tavrıydı. Musaddık ve Milli Cephe temsilcilerinin parlamentoda tasarı lehine yaptıkları heyecanlı konuşmalarda, ülke petrollerinin işletim hakkının AIOC den alınması ve devletleştirilmesini İran'ın bağımsızlığının vazgeçilmez koşulu olarak vurgulayan ifadelere yer verilmişti. Razmara ise Hükümet adına yaptığ1 konuşmada, teknik, ekonomik ve politik nedenlerle petrollerin millileştirilmesinin imkânsız olduğunu söyledi. ( Yazıc1, 2014: 490 ) Diğer yandan, petrol şirketinin üretim yerlerinde işçiler grevlere başlamış, sokaklarda TUDEH ve Kaşhani'nin teşvik ve yönlendirmeleriyle yoğun protesto eylemleri başlatılmıştı. Yine de AIOC ile İran petrollerinin kaderi parlamentoda yapılacak oylama ile kesinleşecekti. Tasarı henüz oylanmadan Başbakan Razmara 7 Mart 1951 günü Fidayin-i İslâm adlı silahlı bir örgüt tarafından düzenlenen bir suikast sonucu öldürüldü. ( Keddie,2003: 124, Ghods, 1993: 33 ) Şimdi kriz bir başbakan cinayeti ile daha da derinleşmiş ve içinden çıkılması adeta imkansız hale gelmişti.

\section{6-Musaddık’ın Başbakanlığa Atanması ve İran Petrollerinin Devletleştirilmesi}

Razmara'nın öldürülmesinden sonra Şah yeni hükümeti kurma görevini Hüseyin Ala'ya verdi. 12 Martta göreve başlayan Ala Hükümetinin krize çözüm bulabileceğine inanan pek yoktu. Her ne kadar göreve başladıktan kısa bir süre sonra, işçilerin greve son verecekleri ve 3500 işçinin işbaşı yapacağını kamuoyuna açıklayarak işlerin düzelmekte olduğu mesajını vermeye çalışsa da, Hüseyin Ala başbakanlıkta sadece 46 gün kalabildi. Parlamento'nun petrollerin millileştirilmesi çağrısıyla özel bir toplantı kararı alması üzerine istifasını Şah'a sundu. Bu arada parlamento toplantıya katılan 91 milletvekilinden 79 'unun kararıyla İran petrollerinin millileştirilmesini öngören yasayı onaylamıştı. Tasarıya evet oyu veren milletvekillerinin tamamı aynı zamanda Şah'a başbakanlığa Musaddık'ın getirilmesini öneren ortak bir metni imzalamışlardı. Muhalefetin kontrolündeki eylemlerin dalga dalga yayılması üzerine, Şah çıkar yol olarak, Hükümeti kurma görevini Milli Cephe Lideri Dr. Muhammed Musaddıka vermek zorunda kalmıştı. ( Milliyet, 18.04.1951, New York Times, April 28, 1951 ) Bu İran siyasal hayatında yeni bir dönemin başlangıcı idi. Muhalefet ilk defa kendi gücü ile iktidar olma şansı elde etmişti.

Yeni Hükümeti kuran Musaddık, Parlamentodaki Milli Cephe'nin öncüsü olsa da, her hangi bir siyasi partinin lideri değildi. Milli Cephe daha çok bağımsızlık yanlısı milletvekillerinin gönüllü işbirliğine dayanıyordu. Bu ittifakın öncelikli hedefi de petrollerin millileştirilmesi ve AIOC nin faaliyetlerine son verilmesiydi. Parlamento dışında da Musaddık'a oldukça büyük bir halk desteği vardı. Küçük orta sınıf, küçük esnaf ve pazar 
tüccarları ve alt düzeydeki mollalar Musaddık'1 destekliyorlard1. Köylüler de Musaddık'a destek verseler de feodallerin kontrollerindeki kesimler çok güvenilir değildiler. Ordunun üst kademesi olmasa bile alt düzeydeki askeri kesim de Musaddık'ın yanındaydı. TUDEH ideolojik farklılıklarına rağmen Musaddık'ın hükümeti kurmasından memnundu. TUDEH dışındaki legal sol partiler de Milli Cephe’ye ve Musaddık Hükümetine destek veriyorlardı. Özellikle Emekçi Parti Lideri Dr. Muzaffer Bagai ve bir çok entelektüel desteklerini açıktan belli ediyorlardı. Ayetullah Kaşhani Cephesi ise Musaddık Hükümetine destek verme kriterini ilk günden itibaren tüm yabancıları ülkeden kovma koşuluna bağlamıştı. ( Richards, 1975: 3 ) Ancak, tüm bu büyük kesimlerin desteğine rağmen, Musaddık Hükümeti'nin işi hiç de kolay değildi. Çünkü Musaddık'ın kendisine destek veren gruplarla hiçbir organik bağı yoktu. Musaddık'ın kendisi liberal bir düşünceye sahip olmasına rağmen kendisini destekleyen grupların çok azı aynı görüşü benimsiyordu. Destek biraz da konjektürel nedenlere dayanmaktaydı. Konjektür nedeniyle kendisine destek veren grupların desteklerini çekmeleri de kolay olacaktır.

Musaddık Hükümeti'nin kurulması İran üzerinde çatışan ülkelerde de değişik duygular ve beklentilerle karşılandı. Sovyetler, Musaddık Hükümeti'nin iktidara gelişinin AIOC ile yaşanmakta olan anlaşmazlık sonrasında olduğunun farkında idi. Bu anlaşmazlığın büyümesi Sovyetlerin arzulayacağı bir şeydi. Ayrıca Sovyetler, 1946 yılından beri, İran’la ilişkilerinin zayıflaması ve ticari ilişkilerin kesilmesi yaşanan kayıpların sona ereceği beklentisi içerisindeydi. Musaddık Hükümeti ile İran'la kapılar yeniden açılabilirdi. İngiltere ise AIOC ye muhalefet ederek iktidara gelen Musaddıktan hiç memnun değildi. Musaddık Hükümeti'nin ilk ele alacağı konunun petrollerin devletleştirilmesi olacağının bilincinde ve endişeliydi. Ancak ABD'nin desteği olmadan Musaddık Hükümetiyle anlaşabilmesi mümkün görünmüyordu. ABD ise İngiltere'nin aksine Musaddık Hükümetine karşı hemen cephe alınmasına taraf değildi. CIA nın Musaddık'a düzenlenecek darbe sürecine kadarki raporlarında, ABD yönetimine uzlaşı önerileri sunulmakta ve baskının Musaddık’1 Sovyetlere itebileceğine dikkat çekilmektedir. ( Guardian, August 19, 2013 ) Her ne kadar ABD bu raporların da etkisiyle Musaddık Hükümeti ile İngiltereyi uzlaştırmak için bir takım çabala içerisine girse de Musaddık'ın geri adım atmaya niyeti yoktu.

Musaddık Hükümeti'nin göreve başladığı günlerde, İngiltere’nin Tahran Büyükelçisi Shepherd Şah'ı ziyaret ederek kendisinden parlamentonun onayladığı millileştirme yasasını hemen onaylamamasını ve bir süre geciktirmesini talep etti. Shepherd, ABD'nin Tahran Büyükelçisi Grady'den de kendilerini desteklemesini ve Şah'a baskı yapmasını istedi ise de büyükelçi böyle bir yetkisinin olmadığı karşılığını verdi. ABD Musaddık'a baskı yapılmasının sorunu daha da büyük bir çıkmaza sürükleyeceğinden endişe duyuyordu. Hatta Grady, Şaha ve Musaddık'a baskı yapmak yerine, Musaddık Hükümetine destek vererek İngiltere ve şirketle İran arasında arabuluculuk yapmayı denedi. Nitekim Büyükelçi Grady, Musaddık'la yaptığı bir görüşmenin ardından, ABD’nin İran'a daha önce imzalanmış anlaşmalarla yapmakta olduğu yardımın süreceğine dair güvence verdi. ( Paine and Schoenberger, 1975: 23 ) İngiltere ise, Parlamento'nun çıkardığı millileştirme yasasına karşı sert bir tutum takındı ve Musaddık Hükümeti'nin görüşme taleplerine kulağını tıkayarak Tahran'a müzakere için hiçbir yetili göndermedi. İngiltere Musaddık Hükümeti’ni askeri müdahale ile tehdit ederek sonuç alacağını umuyordu. Bunda ne kadar ciddi olduğunu göstermek için de bir paraşüt taburunu, o dönemde 
yönetiminde bulundurduğu, Kıbrıs'a gönderdi. AIOC nin Abadan Bölgesindeki personelini tahliye kararı aldı. Musaddık Hükümeti de geri adım atmak niyetinde değildi. İngiltere'nin müdahale tehdidini dikkate almak bir yana AIOC nin artk Milli Iran Petrol Şirketi ( NIOC ) adını aldığını açıkladı. ABD ise gelinen noktada daha da tedirgin olmaya başladı. Çünkü İngiltere'nin İran'a bir müdahalesi durumunda Sovyetler 1921 Anlaşmasını bahane ederek işin içine girebilirlerdi. ( Marsh, 2003: 5 )

ABD krizin sıcak bir çatışmaya varma olasılığına karşı daha aktif bir tutum içine girdi. Başkan Truman'ın görev süresinin son aylarıydı. Bu nedenle başkanın özel temsilcisi sıfatıyla en deneyimli diplomatlardan biri olan Averell Harriman'1 sorunun çözümüne yardımcı olması için, Temmuz 1951'de, Tahran'a gönderdi. Harriman II. Dünya Savaşı sırasında 1943' de toplanan Tahran ve 1945'deki Yalta Konferanslarında yer almış kriz yönetimi becerisi oldukça güçlü bir diplomattı. Harriman Tahran'a 15 Temmuzda vardı. Ancak bu tarih ABD ile Sovyetlerin İran'da ilk karşı karşıya geldikleri 1946 yılında TUDEH tarafından öncülük edilen gösterilerin 6. Yıldönümüydü. Harriman Tahran hava alanında kızgın kalabalıkların ABD karşıtı sloganlarıyla karşılandı. Her ne kadar, İran'a görev yaptığı dönemdeki dostlarını ziyaret amacıyla geldiğini söylese de, kalabalıkları yatıştırmak kolay olmadı. İçişleri Bakanı ve aynı zamanda polis birliklerinin koordinatörü olan General Zahidi'nin emriyle güvenlik kuvvetleri kalabalığa müdahale ettiler ve çatışmalarda 15 kişi öldü ve 200 kişi de yaralandı. ( Paine and Schoenberger, 1975: 23 ) Harriman, Tahran'da işinin hiç de kolay olmayacağını ilk gün karşılaştığ 1 atmosferden fark etmişti. Olay sadece Musaddık Hükümeti ile AIOC arasındaki bir anlaşmazlıktan çok daha derindi ve ABD aleyhtarlığı da küçümsenemeyecek bir boyuta doğru gitmekteydi.

Harriman ilk günde karşılaştığ 1 manzaraya rağmen yine de iyimserliğini koruyordu. Tahran'a vardıktan sonra ilk ziyaretini Başbakan Musaddık'a yaptı. Yanında petrol konusunda uzman yardımcıları da getirmişti. Bunlardan Walter J. Levy, Musaddık'a İran'ın petrolleri millileştirmesinin avantajları yanında dezavantajlarının olacağına dair bir brifing verdi. İran'ın petrolleri üretmede yeterli personele sahip olmadığı ve üretse bile bunu uluslararası pazarlara taşıyacak tankerlere sahip olmadıklarını hatırlattı. Ancak Musaddık çok kararlı bir şekilde bunlara aldırış etmeyeceklerini söyleyince, Harriman Musaddıkla uzlaşmanın neredeyse imkânsız olduğuna kanaat getirdi ve Musaddık'1 dolaylı yollardan etkilemeyi denedi. Şah'1 ziyaret ederek, Musaddık'a baskı yapmasını ima ettiyse de Şah millileştirmenin aleyhinde hiçbir ifade kullanmaya yanaşmadı. Bunun üzerine Harriman Tahran'da İranlı gazetecilerin katıldığı bir basın toplantısı düzenledi. Toplantıda İran Halkının duygularını anladığını ancak çözüm için mantıkla krize gögüs gerilmesinin gerektiğini söyleyince, bir gazeteci ayağa fırlayarak bütün gazetecilerin ve İran Halkının millileştirme kararının arkasında olduğunu bağırarak söyleyince, herkes salonu terk etmiş ve Harriman salonda tek başına kalmıştı. ( New York Times, July 19, 1951 ) Bunun üzerine Harriman, Musaddıkla birlikte İran'da kitleleri etkileyebilen aktörlerle sorunu konuşmaya karar verdi ve sürpriz bir şekilde Molla Kaşhani'yi ziyaret etti. Kaşhani Harriman'1 devamlı olarak yaşadığı tek gözlü odasında kabul etti. Harriman odaya girerken İran geleneklerine saygılı davranarak ayakkabılarını odanın kapısının önünde çıkarmıştı. Harriman'ın Kaşhani'den isteği, Başbakan Musaddık'1 İngiltere ile kesintiye uğrayan krizle ilgili görüşmeleri yeniden başlatmaya ikna etmesiydi. Ancak Kaşhani, bırakın 
bu isteği yerine getirmeyi, eğer Musaddık İngiltere ile bu konuyu görüşürse onun da sonunun Razmara gibi olacağını söyleyince Harriman soğukkanlılığını korumaya çalışarak odadan ayrıldı. ( Kinzer, 2004: 136 ) AIOC nin devletleştirilmesi konusunda, Musaddık Hükümeti ve onu destekleyen geniş kitleler geri adım atmaya yanaşmadıklarına göre, krizi çözmek ve bir savaşı önlemek için İngiltere'yi ikna etmekten başka çare kalmamıştı.

\section{7-Krizin Birleşmiş Milletler Güvenlik Konseyi ve Uluslararası Adalet Divanın’a Götürülmesi}

Harriman, krizin İngiltere ile İran arasında bir savaşa dönüşmemesi için, Tahrandan Londra'ya geçerek üç gün süreyle Hükümet yetkilileriyle toplantılar yapıp olayın vahametini anlatmaya çalıştı. Ancak hükümet üyeleri kriz karşısında izlenecek politika konusunda bölünmüşlerdi. Bazı bakanlar İran'la görüşmelerin yeniden başlatılmasından yana tavır alırken bir kısım bakanlar ise İran'a müdahaleden ve özellikle Musaddık Hükümeti’nin devrilmesinden söz ettiler. Müzakereden yana olanların çabası ve Harriman'ın bireysel gayretleri ile bazı İngiliz temsilciler Tahran'a gönderildilerse de bunların daha önceki koşulları tekrarlamaları nedeniyle hiçbir sonuç elde edilemedi. Bu süreçte İran'dan petrol akışı durduğu için, AIOC ile birlikte İran'ın petrolden elde etmiş olduğu gelir de ortadan kalkmıştı. İngiltere'nin politikası biraz da petrol gelirlerinden yoksun Musaddık Hükümeti'nin halkın baskılarına dayanamayacağı ve pes edeceği beklentisiydi. ( Majd, 1995: 450 ) Diğer yandan İngiltere Musaddık'ın millileştirmede geri adım atmaması durumunda şirkete tazminat ödemek için yeterince kaynak bulamayacağ için yumuşayacağını umut ediyordu.

Musaddık, İngiltere'nin kendisini ekonomik yönden sıkıştırarak geri adım attırmaya zorlayacağının farkında idi. Nitekim İngiltere İran'a pirinç ve çelik ihracatını durdurma kararı almıştı. Ancak bunlar Musaddıkı geri adım atmaya zorlayacak yaptırımlar olmaktan uzaktı. Bununla birlikte Musaddık İngiltere ile yaşanan krizle dünya ile ilişkilerin karıştırılmaması gerektiğinin bilincinde idi. Dünya Bankasına başvurarak hem devletleştirilmiş olan şirketin üretim masraflarını hem de giderek ağırlaşmaya başlayan ekonomik problemleri aşabilmek için 120 milyon dolarlık bir kredi talebinde bulundu. ( Paine and Schoenberger, 1975: 24 ) Bununla uluslararası kamuoyuna ve özellikle ABD’ye vermek istediği mesaj gayet açıktı. Musaddık sorunun İngiltere ve AIOC ile yaşanmakta olduğunu ve İran'1 dünyadan izole etmeye niyeti olmadığını göstermek istiyordu. Ancak Dünya Bankasıyla sürdürülen uzun müzakerelerden bir sonuç elde edilememiş ve görüşmeler askıya alınmıştı. Çünkü Musaddık Dünya Bankasına krediye teminat olarak işletilecek petrolden elde edilecek geliri karşı1lık göstermiş, banka da sorunun devam ettiğini gerekçe göstererek krediyi onaylamayı reddetmişti. ( New York Times, August 19, 1953 )

Petrol krizinin uzaması sadece İran'1 değil İngiltere'yi de hem ekonomik hem de politik yönden etkiliyordu. Abadan petrol bölgesinde petrol üretiminin durması nedeniyle İran petrolünün dünya pazarlarına akışı durmuştu. Endüstrileşmiş ülkeler de piyasalarda ihtiyaç duydukları petrolü bulamama endişesiyle karşı karşıya kalmışlardı. İngiltere bu durumdan yararlanmak İran üzerinde baskı kurabilmek amacıyla konuyu Birleşmiş Milletler Güvenlik 
Konseyi'ne götürme kararı aldı. Musaddık bu firsatı kaçırmadı ve bizzat kendisi New York'a giderek sorunu anlatmaya karar verdi. Musaddık New York'a giderken önce Roma sonra da Amsterdam'a uğramıştı. Her iki Avrupa Başkentinde de hava alanlarında ve caddelerde coşkulu kalabalıkların yoğun desteği ile karşılandı. Yaşlıydı ve önemli sağlık sorunları ile uğraşıyordu. 8 Ekim 1951'de New York'a vardı. Uçağın merdivenlerinden doktoru ve aynı zamanda oğlu olan Gulam Hüseyin Musaddık'ın yardımıyla indi. Hem uzun uçak yolculuğunun etkisi hem de sağlık sorunları nedeniyle gazetecilerin yoğun sorularına cevap vermek yerine onlara yazılı bir metin dağıtmayı tercih etti. Metinde şu ifadelere yer verilmişti. ( Kinzer, 2004: 152 ) "Zalim ve emperyalist bir şirketin muhtaç ve çıplak insanlara ait olan zenginliği nasıl çaldığının ve Birleşmiş Milletler'in de bu cinayeti onaylamak üzere nasıl kullanıldığını anlatma sözü veriyorum ".

Güvenlik Konseyinde ( GK ) yapılan görüşmelerde bir anlaşmaya varılamadı. İngiltere'nin çözüm için ileri sürdüğü öneriler ABD'nin baskısıyla yumuşatıldı. Hindistan ve Yugoslavya gibi bazı ülkelerin verdikleri değişiklik önerileri ile tamamen zayıflatıldı. İran ise İngiltere'nin önerilerini bütünüyle reddediyordu. Üç gün devam eden görüşmelerde, Musaddık sağlığının iyi olmaması nedeniyle kendisi konuşmamış ve hazırladığı metni okuması için İran'ın Birleşmiş Milletlerdeki Büyükelçisi Muhammed Salih’e vermişti. İki saat süren konuşmada, ilk olarak, İngiltere'nin İran'1 sömürmesine dramatik ifadelerle değiniliyor ve Güvenlik Konseyi'nin böyle bir konuda karar verme yetkisinin bulunmadığının altı çiziliyordu. Görüşmelerin son gününde Konsey, sorunun tartışılmasını belirsiz bir tarihe ertelemek için oylama yapılmasına karar verdi. İngiltere ve ABD çekimser kalmasına rağmen karar kabul edildi. Güvenlik Konseyi'nin kararı İngiltere'nin diplomasideki yenilgisi fakat İran'ın ama daha çok Musaddık'ın zaferi olarak ABD ve dünya basınında öne çıktı. Bununla birlikte petrol krizi daha da büyük bir çözümsüzlüğe sürüklendi. Artık Musaddık millileştirme projesini daha da ileri taşıma konusunda kararlıydı. ABD Başkanı Truman bu durumu fark ettiği için Musaddık'1 Washington'a davet etti. ( New York Times, Washington Post, Guardian, October 20, 1951 , Kinzer, 2004: 160 )

Washington daveti Musaddık için derdini hem ABD Kamuoyuna hem de dünyaya anlatmada yeni bir fırsattı. Ancak, Musaddık Washinton'a gitmeden önce, müthiş bir diplomasi atağı yaparak Philadelphia’ya uğradı ve Bağımsızlık Binasını ziyaret etti. Bu ziyaretle ABD Kamuoyuna ve daha çok Truman Yönetimine vermek istediği mesaj çok açık ve bir o kadar da anlamlıydı. İngiltere sömürüsüne karşı isyan eden Amerikalıların İran Halkının da yine İngiltere ile yaşadığı benzer sorun karşısında haklarına saygı duyulması. Ertesi gün Amerikan basınındaki en önemli haber Musaddık'ın bu sembolik ziyaretiydi. ( New York Times, Washinton Post, Wall Street Journal, October 23, 1951 ) Musadık Truman'la Beyaz Sarayda görüştü. Görüşmede Truman Musaddık'a anlaşmazlık konusunda İran'a hak verdiklerini ancak krizin bir çatışmaya dönüşmesi halinde Sovyetlerin müdahale için firsat beklediklerini de hatırlatmayı ihmal etmedi. Musaddık ve İran Heyeti ile ABD Dışişleri Bakanı Dean Acheson ve yardımcısı McGhee arasında krizin çözümüne yönelik uzun müzakereler yapıldıysa da tam bir uzlaşmaya varılamadı. Müzakerelerde ABD’nin, İran'ın sahip olduğu petrol kaynakları üzerindeki kontrol hakkının kabul edilmesine karşılık, dağıtım işinin tam yetkili bir uluslararası tarafsız şirkete verilmesi ve İngiltere'ye de petrolün pazarlamasının bırakılması şeklindeki 
önerisi Musaddık tarafindan kesin olarak reddedildi. ( Keddie, 2008: 125, Kinzer, 2004: 162 ) Washington görüşmelerinden bir sonuç alınamamış ancak Musaddık İran'a politik olarak daha güçlü bir lider olarak dönme firsatı elde etmişti.

Musaddık Tahran'a dönerken bilinçli bir şekilde Kahire'yi ziyaret etti. İran'la birlikte Orta Doğu'nun en önemli diğer ülkesi olan Mısır'ın da İngiltere ile yaşadığı önemli sorunlar vardı. Böylece bu ziyaret İngiltere emperyalizmine karşı mücadele eden ülkelerin dayanışması anlamını taşıyordu. Musaddık Kahire'de de İngiltere karşıtı kalabalık halk desteği ile karşılandı. Kahire'de birkaç gün kalması onun bu ziyaretinin sadece geçerken uğrama olmadığını gösteriyordu. Nitekim iki ülke arasında imzalanan Dostluk ve İşbirliği Anlaşması iki ülkenin İngiltere Emperyalizmine karşı dayanışmasını simgeliyordu. ( Kinzer, 2004: 164 ) Musaddık kendi ülkesinde yeterince popüler ve güçlü bir halk desteğine sahipti. Birleşmiş Milletler Güvenlik Konseyi'ndeki toplantılara katılmak için çıktığı yurtdışı seyahatler uluslararası bir karizma kazanmasında önemli firsat oldu. Sirasıyla Roma, Amsterdam, New York, Philadelphia, Washington ve son olarak Kahire'de gördüğü ilgi onu dünyanın en önemli politik aktörü haline getirdi. Nitekim, 1952 yılında Times Dergisi Musaddık’ı "yılın adamı " seçti. ( Kinzer, 2004: 166 )

Birleşmiş Milletlerdeki görüşmelerden eli güçlenerek ülkesine dönen Musaddık İngiltere'nin baskı ve tehditlerine karşı daha büyük bir cesaret kazandı. İngiltere ise Musaddık Hükümeti'ne karşı stratejisini iki seçeneğe dayandırdı. İlk olarak İran'a karşı bir askeri müdahalede bulunmak bu mümkün olmadığı takdirde Musaddık Hükümeti'ni devirmek. Ancak her ikisi de bir takım risklerle dolu yöntemlere girişmeden önce, son bir umut olarak, anlaşmazlığı daha önce götürmüş olduğu Uluslararası Adalet Divanı'nın vereceği kararı beklemeye koyuldu. İngiltere'nin iddiasına göre, İngiltere'nin İran yönetimiyle imzalamış olduğu ve petrollerin AIOC tarafından işletilmesini öngören anlaşma 1993 tarihine kadar geçerliydi ve bu süre dolmadan şirketin arzusu dışında tek taraflı olarak sona erdirilemezdi. Ancak İngiltere Uluslararası Adalet Divanı'ndan da umduğu sonucu elde edemedi. Çünkü Adalet Divan1, 23 Temmuz 1952'de verdiği kararla, İran ile İngiltere arasındaki petrol anlaşmazlığı konusunda her hangi bir karar vermeye yetkili olmadığını 5'e karş1 9 oyla ilan etti. Uluslararası Adalet Divanı'ndaki görüşmelerde İran'ın tezini savunan heyetin başında yine Başbakan Musaddık vardı. ( New York Times, April 28, 1951, July 23, 1952 ) Karar şüphesiz ki İngiltere'nin beklediği bir sonuç değildi. İngiltere bu karardan sonra İran'a askeri müdahalede bulunmak ya da Musaddık Hükümeti’ni devirmenin hesaplarını daha ciddi biçimde yapmaya başladı.

\section{8- Musaddık Hükümeti’nin Devrilmesine Doğru}

1952 yılının yaz aylarından sonra İran-İngiltere krizini etkileyen ve Musaddık Hükümeti'nin devrilmesine yol açan birçok olay art arda yaşandı. Musaddık'ın Kahire ziyaretinden kısa bir süre sonra Mısır'da Hür Subaylar Komitesi tarafından Kral Faruk devrilerek Cumhuriyet'e geçilmesi için hazırlıklar yapılmaya başlandı. Musaddık bu olaydan çok etkilendi. Ona göre İran'ın yaşamakta olduğu iç ve dış sorunların baş sorumlusu sadece 
yabancı ülkeler değil belki daha çok Şahlık Rejimi ve Muhammed Rıza Pehleviydi. Emperyalizmin sömürüsünden kurtulmanın yolu Şah'lığa son vermekten geçmekteydi. Ancak bunu başarabilmenin yolu dışarıda kazanılmış olan prestijin meyvelerini iç politikada toplamaktan geçmekteydi. Kamuoyunun desteğini daha güçlü şekilde arkasına alabilmek için yetkilerinin genişletilmesini arzu ederek, açıkça, Şah’tan Savunma Bakanlığı'nın kendi uhdesine verilmesini istedi. Amacı şüphesiz ki yaşanan olaylardan dolayı kendisine karşı yapılabilecek bir askeri darbeyi önlemekti. Ancak Şah'ın buna yanaşmaması üzerine 17 Temmuz 1952'de istifa etti. ( Paine and Schoenberger, 1975: 26 ) Şüphesizki, Musaddıkın istifası yenilgiyi kabul değildi ve daha güçlü bir şekilde dönmeyi hedefliyordu. 19 Temmuzda Şah yeni Hükümeti kurma görevini Ahmet Kavam'a verdi. Kavam 1946'da Sovyetlerle Bat1 arasında yaşanan kriz döneminde başbakandı ve oldukça deneyimli bir politikacıydı. Şah 22 Temmuzda, Kavam'dan bir hükümet kurmasını ve İngiltere ile yaşanmakta olan petrol krizini çözmesini istedi. Kavam, Hükümeti kurduğu gün yaptığı açıklamada, AIOC ile yaşanan sorunla İngiltere ile ilişkilerin karıştırılmaması gerektiğini söyleyerek, İran'ın bir an önce bir siyasi istikrara ve sükunete ihtiyacı olduğunu ve bunun içinde öncelikle Kaşhani’nin taraftarlarının yönlendirdikleri terör olaylarının sona erdirilmesi gerektiğini vurguladı. ( Cottam, 1970: 10, Efimenco, 1955: 398 )

Kavam tarafından kurulan hükümet sadece 5 gün işbaşında kalabildi. Musaddık'1 destekleyen kitleler Kavam Hükümeti'nin İngiltere ve AIOC nin isteklerini yerine getirmek için kurdurulduğunu ileri sürerek kanlı gösteri ve eylemlere başladılar. Bu olaylarda Kaşhani'nin taraftarları ve TUDEH in yer altına çekilen kanadı baş rolü oynuyorlardı. Kaşhani'nin, gösterilerin Müslümanların boğazından İngiliz zinciri çıkarılıncaya kadar süreceğini açıklaması üzerine, Şah geri adım atarak, Kavamı başbakanlıktan aldı ve yeniden Musaddıkı Hükümeti kurmaya davet etti. Şah'ın Musaddıkı eylemleri sona erdirmek için yeniden işbaşına getirmesi esasında bir ihtilâl anlamına geliyordu. Şimdi Musaddık için bu siyasi zaferin meyvelerini toplama zamanı gelmişti. Yeni Hükümet Parlamento'daki 64 üyenin 61'inden güven oyu aldı ve Senato'nun çoğunluğu da ona destek verdi. Bunun ardından Musaddık Parlamentodan 13 ay süreyle parlamento yetkisi istedi. 5 üyenin katılmadığ toplantıda 59 üyenin 57 si isteği onaylayarak Musaddık'a olağanüstü yetkiler tanıdı. ( Efimenco, 1955: 399 ) Böylece Musaddık, bir yandan arkasında büyük bir halk ve parlamento desteği ile antidemokratik bir rejime ve dışarıda emperyalizme karşı mücadele yürütürken, diğer yandan otoriterlik ile diktatörlük arasındaki bir noktaya doğru hızla savruluyordu.

Musaddık 1952 yılının sonlarına doğru başarı merdivenlerini hızla tırmanırken ve Şah’la açık bir çatışmanın içerisine girmeye hazırlanırken İngiltere'de de parlamento seçimlerini Muhafazakâr Parti kazanmıştı. II. Dünya Savaşı yıllarındaki siyasi kadro yeniden işbaşına gelmiş, Başbakan Winston Churchill Dışişleri Bakanı da Antony Eden olmuştu. İngiltere'de İşçi Partisi'nin iktidardan düşmesinin sebepleri arasında İran'la yaşanmakta olan petrol anlaşmazlığındaki başarısızlığı ilk sırada gösteriliyordu. Diğer yandan savaşla birlikte İngiltere'nin dünyanın çeşitli bölgelerinde uğradığı kayıpların Churchill'in politikadaki deneyim ve şöhreti sayesinde yeniden telafi edileceği beklentisi hakimdi. Bu açıdan ilk sınav belki de İran'la yaşanan petrol krizi olacaktı. Muhafazakâr Parti ve Churchill'in yeniden iktidara gelmesinin ABD de de olumlu bir hava yarattığı dikkati çekmektedir. İşçi Partisi'nin 
solcu bir damara sahip olması ve Sovyetler Birliği ile yaşanmakta olan ve ideolojik bir temele dayanan Soğuk Savaş özellikle Truman Yönetimiyle İngiltere arasında bir soğukluk yaratmıştı. Clement Atlee'nin İran'a askeri müdahale seçeneğine ABD sicak bakmazken Churchill'e hayır denilmesi o kadar kolay olmayacaktır. Cünkü Churchill II. Dünya Savaşı'ında ABD'nin en önemli kader ortağı idi.

Musaddık'ın devrilmesine yönelik kararın alınmasında, 1952 yılı sonunda ABD'de yapılan başkanlık seçimi sonucunda başkanlığa Dwight D. Eisenhower'ın seçilmesi de etkin bir rol oynad1. ( Cottam, 1970: 11 ) Demokrat Partili Truman Yönetimi petrol krizinin aşılması için önemli çabalar harcamış ve daha çok tarafları sorunun çözümü için uzlaşmaya davet etmişti. Özellikle de İngiltere'nin askeri müdahale önerisine, yukarıda belirtildiği gibi, mesafeli durmuş ve işin içine Sovyetlerin girmesine zemin oluşturacağı gerekçesiyle karşı çıkmıştı. Oysa Eisenhower Komünizme karşı toleranssızlığı ile bilinen asker kökenli ve bu konudaki tutumuyla bilinen Cumhuriyetçi Partiye mensuptu. II. Dünya Savaşı sırasında Avrupa'da Müttefik Kuvvetler Komutanlığı ve NATO'nun kurulmasının ardından da NATO Başkomutanlığı görevlerinde bulunmuştu. Dışişleri Bakanlığı'na getirdiği John Foster Dulles da kendisi gibi Sovyetlerin yayılmalarını önlemeye yönelik politikaları ile şöhret kazanmışlardı. Mc Cartism'in onun başkanlığı döneminde yaşanmış olması komünizme bakışı için önemli bir örnek olarak gösterilebilir. Eisenhower, başkanlığının ilk günlerinde, her ne kadar Musaddık Hükümeti'ne karşı destek verip vermeme konusunda bir ikilem içerisinde olmuşsa da çok geçmeden onun bir darbe ile devrilmesine yeşil ışık yakmıştır. Çünkü CIA Başkanı ve aynı zamanda Dışişleri Bakanı Dulles'ın kardeşi olan Allen Dulles İran'ın her geçen gün Sovyetlere ve komünizme doğru kaymakta olduğu konusunda onu ikna etmişti. ( Kinzer, 2004: 193, Cottam, 1970: 11 )

ABD ve İngiltere'nin birlikte Musaddık'1 devirmeye karar vermelerinde Sovyet Lideri Josef Stalin'in ölümünün de etkili olduğunu göz önünde bulundurmak gerekir. ABD ve İngiltere Musaddık Hükümetini devirmeyi ciddi biçimde düşünmeye başladıkları anda Stalin'in 6 Mart 1953'de ölümü operasyonu kesinleştirmiştir. Stalin'in ölümünün Sovyet Yönetiminde yarattığı boşluk ve Stalin'in yerini almak için çaba gösteren politikacılar arasında başlayan rekabet Sovyetlerin İran'a müdahale olasılığını zayıflatmıştı. İngiltere Başbakanı Churchill Sovyetlerin müdahale riskinin kalmadığını öne sürerek İran'a askeri müdahalede bulunulması seçeneğini güçlü biçimde savunmasına rağmen $A B D$ ve Eisenhower Yönetimi ve özellikle Dışişleri Bakanı Dulles ile kardeşi CIA Lideri Allen Dulles sorunun çözümü için Musaddık Hükümeti'nin devrilmesinin daha doğru olacağını savundular. CIA'nın öncülüğündeki darbe operasyonunun adı da "Ajax “ olarak belirlenmişti. ( Marsh, 2003: 24 )

\section{9- Darbe ve Sonrasi}

1953 Mayıs ayından itibaren İran'da siyasi gerginlikler tırmanmaya başladı. 1952'deki parlamento seçimlerinde çoğunluğu kazanan ve parlamentodan olağanüstü yetkiler elde eden Musaddık, Şubat 1953'de, Şah Muhammed Rıza Pehlevi'yi tahttan çekilmeye zorladı. TUDEH Musaddık’ın bu hareketini bütün gücüyle destekliyordu. Çünkü İran'da Cumhuriyet ilân 
edilirse bunun gelecekte Sosyalizme evrilmesi daha kolay olabilirdi. Cumhuriyet ilân edilmesi ve Şahlığın yıkılması emperyalistlere karşı işbirliğinin bir zaferi olacaktı. Böylece İran'da Marxist, Nasyonalist ve İslami gruplar farklı beklentilerle emperyalizm karşıtlığı ekseninde bir ittifak kurmuş oluyorlardı. ( Behrooz, 2001: 364 ) Ancak Musaddık'ın Şah'1 tahttan çekilmeye zorlaması bir yandan Milli Cephe içerisindeki grupları diğer yandan da Şah’tan yana olan ve ABD ile İngiltere ile dirsek temasında olan General Zahidi yönetimindeki orduyu harekete geçirdi. Musaddık her ne kadar Savunma Bakanlığı'nı bu tehlikeye karşı kendi üzerine almışsa da ordunun eğilimi genelde Şah’tan yanaydı. ( Westwood, 1965: 128)

Musaddık'ın İran'da rejim değişikliğine yönelik girişimi bir çok engelle karşılaştı. Şahlık rejimine son verileceğinin açıklanması ve Musaddık'ın kendisini bir takım yetkilerle donatması bir çok taraftarının bile kendisini terk etmesine neden oldu. Parlamentodaki Milli Cephe'de yer alan 56 milletvekili istifa ettiler. Musaddık parlamentonun feshedilmesini ve kafasındaki rejim değişikliğini milli bir referanduma götürme kararı almışsa da muhalefet referanduma katılmayı reddetti. Referanduma katılanların \%99'u Musaddık'ın istediği gibi oy kullanmışsa da bu gerilimi daha çok artırmaktan başka bir işe yaramadı. ( Paine and Schoenberger, 1975: 26 ) Çünkü İran Anayasası'na göre ülkede siyasi bir konuyla ilgili referandum isteme yetkisi sadece Şah'a tanınmıştı. ( Efimenco, 1955: 400 ) İngiltere ile İran arasında başlayan petrol anlaşmazlığı İran iç siyasetinde şimdi tam bir karmaşa ve kaos ortamına dönüşmüştü.

Milli Cephe'nin Musaddık'a verdiği destek dış güçlerle mücadele ve İran'ın milli çıkarlarının korunması önceliğine dayanıyordu. Ancak Musaddık'ın İran siyasetini kökünden değiştirecek radikal siyasi kararları için aynı şekilde bir destek bulabileceğini hesap edememesi belki de bir darbe ile karşılaşmasının en önemli nedeni olmuştur. Her şeyden önce, gerek TUDEH gerekse Kaşhani'nin desteğinin demokrasiyle bir ilgisi yoktu. Musaddık ABD ve İngiltere'ye karşı mesafeyi açtıkça Sovyetlere kendi istemese de yaklaşmış görünüyordu. Özellikle BBC ve Amerika'nın Sesi gibi radyo yayınlarının Musaddık'ın emriyle yasaklanması bu yöndeki algının en somut delilleri olarak görüldü. ( Marsh, 2003: 8 ) Bu algının etkisiyle parlamentodaki birçok milletvekili kendisinden uzaklaştı. Radikal Dini Lider Kaşhani'nin kendisini terk etme gerekçesi de ironik bir şekilde Komünizm'e kayması ve kendisini diktatörlük yetkileriyle donatması olarak açıklandı. Kaşhani’nin Milli Cepheden ayrılması şüphesiz ki Musaddık için büyük bir kayıptı. Onun ayrılmasından sonra kendisini parlamentoda destekleyen sadece iki dini lider kalmıştı. Ancak bundan daha önemlisi Kaşhani'nin Musaddıkı terkettikten sonra Saray ve İngilizlerle işbirliği yapmasıydı. Kaşhani ile birlikte Musaddıktan desteğini çekmekle kalmayan ve adeta Milli Cephenin altını oyan bir başka kişi de başlangıçta ona destek veren Emekçi Parti Lideri Kerim Bagai idi. ( Richards, 1975: 3 ) Bu algıyı yok etmek Musaddık için hiç de kolay değildi. Halkın önemli bir kesimi hala onunla beraberdi fakat profesyonel gruplar karşısında organize olmaları kolay değildi.

İran'daki bu siyasi kaos ortamı Musaddık'ın devrilmesini kolaylaştırdı. CIA öncülüğündeki operasyon hazırlıkları Ağustos 1953 başından itibaren hız kazandı. Operasyon İngilizlerin MI6 istihbarat örgütüyle birlikte planlandı. Plân, basitçe, Tahran'da gösteri ve şiddet hareketlerini yoğunlaştırarak ordunun darbe yapmasına zemin hazırlamak üzerine kurulmuştu. Operasyonu yürütmek üzere CIA lider kadrosundan Kermit Roosevelt Tahran’a 
gitti ve gizlice Musaddık karşıtı gruplar, aşiretler ve Genel Kurmay Başkanı Zahidi ile görüşmeler yaptı. İran Ordusunda daha önce eğitici olarak görev yapmış olan Albay Schwarzkopf da sözde eski dostlarını ve arkadaşlarını ziyaret etmek için Tahran'a gelmişti. Oysa Schwarzkopf'un asıl amacı ordu içerisinde Musaddık Hükümeti'nin devrilmesine karşı çıkacak subayları etki altına almaktı. En azından İran Basını ziyareti böyle algılamış ve aşırı tepki göstermişti. ( Paine and Schoenberger, 1975: 26 ) Aynı günlerde Sovyetler Birliği tarafından Moskova'da, İran'la bütün sorunları müzakereye hazır olunduğu yönünde bir açıklamaya yer verilmesi üzerine Dışişleri Bakanı Fatemi İran tarafının da tam bir anlaşma arzusu içerisinde olduğunu belirtmişti. ( New York Times, August 11, 1953 ) ABD üst düzey yöneticilerinin Tahran ziyaretlerinde bu karşılıklı açıklamaların etkili olduğu söylenebilir.

Musaddık'1n 15 Ağustos 1953'de parlamentoyu feshetmesi üzerine Şah Hazar Denizi kıyısındaki Ramsar yakınlarında bulunan yazlık sarayında Musaddık'ın başbakanlıktan alındığını ve yerine Genel Kurmay Başkanı Zahidi'nin görevlendirildiğini açıkladı. Zahidi’ye Şah tarafindan başbakanlığa atandığı emrini Sarayın güvenlik komutanı Albay Nimetullah Nasıri iletti. 16 Ağustos Cumartesi günü Başbakanlık görevini kabul eden Zahidi Nasıri'den Musaddık'a Şah tarafından görevden alındığını tebliğ etmesini istedi. Nasıri Saraya ait çok sayıda askeri araç ve güvenlik kuvvetleriyle gece yarısında Musaddık'ın evinin etrafinı çevirerek görevinin sona erdiğini bildirmeye kalkınca hiç beklenmedik bir sürprizle karşılaştı. Musaddık, böyle bir girişimle karşılaşacağını tahmin ettiğinden, önceden kendisine bağlı düzenli ordu birliklerinden çok sayıda tank ve askeri aracı evinin etrafına yerleştirerek önlemini almıştı. Nasıri ve beraberindeki askerler eve yaklaştıklarında karşılarında Hükümete bağlı kuvvetleri buldular ve derhal etkisiz hale getirilerek başta Nasıri olmak üzere hepsi tutuklandılar. Bu Musaddık’a karşı bir darbe girişiminin başarısızlı̆ga uğraması demekti. Darbenin lideri Genel Kurmay Başkanı Zahidi derhal ortadan kaybolup gizlenirken Şah ve karısı Saray'a ait bir uçakla Irak'a kaçtı. Musaddık Tahran'da tüm kontrolü ele geçirdikten sonra Irak Yönetiminden Şahı ülkelerinde barındırmamalarını isteyince Şah Bağdat'tan Roma'ya gitmek zorunda kaldı. ( New York Times, August 23, 1953 )

Başarısız darbe girişimi Tahran sokaklarında görülmedik olayları tetikledi. Önce Musaddık taraftarları, kendisine destek için, sokaklara döküldüler ve onlara TUDEH taraftarları da katıldılar. Sokaklardaki gösterilerde “ Şah’a Ölüm “ sloganları atılarak Saray’ın tüm kurumlarına saldırılar düzenlenirken, Musaddık'1 destekleyen basın organları ertesi gün “ İntikam “ ve “ Darağacı “ gibi manşetlerle çıktılar. ( New York Times, August 23, 1953 ) Musaddık taraftarlarının, üç gün süren gösterilerde, aşırı taşkınlıkları onun zaferine zarar verecek boyutlara ulaşmaya başladı. Bunda TUDEH in olayları tırmandırma gayretleri kadar Kermit Roosvel'in göstericiler arasına para dağıtarak yerleştirdiği provokatif adamları da etkili oldular. CIA nın kontrolü altında olduklarından habersiz on binlerce gösterici dalga dalga sokaklara yayılırken bir yandan da Şah'ın resimlerini parçalıyor ve Şah taraftarlarının işyerlerini tahrip ediyorlardı. Musaddık başlangıçta kendi lehine gösteri yapanlara demokratik haklarını kullanıyorlar gerekçesiyle müdahalede bulunmadı. Ancak gösterilerde şiddete başvurulması lehinde olan tablonun kısa zamanda aleyhine dönmesine sebep oldu. ( Kinzer, 2004: 216 ) 
Darbe girişiminin başarıyla savuşturulması Musaddık'1 yanılgıya sürükledi. Tehlikenin tamamen geçtiğine inandı. Sadece Musaddık değil, ABD de başarısızlığı kabullenmiş ve başta Kermit Roosvelt olmak üzere İran'daki tüm CIA elemanlarının ülkeyi hemen terk etmelerini istemişti. Ancak Kermit Roosvelt'in pes etmeye hiç niyeti yoktu. Musaddık lehine gösteri yapanların arasına yerleştirdiği paralı eleman ve provakatörlerin ortalığı yakıp yıkmaları Musaddık aleyhine gösterilere dönüştü. 19 Ağustos günü Şah yanlıları, Kaşhani’ye bağlı milisler, aşiretlere bağlı kalabalıklar Tahran sokaklarını doldurdular. Manzara bir gün öncesine göre tamamen değişmiş, kalabalıklar bir yandan " Şah Çok Yaşa " diye bağırırlarken diğer yandan “ Musaddık’a Ölüm “ çı̆̆lıkları yükseliyordu. Musaddık Hükümeti’ne bağlı polis ve askerlerin göstericilere müdahale etmesi sokakların savaş alanına dönmesine neden oldu. Roosvelt'in paralı adamları çatışmalarda baş rolü oynuyordu. Polis kuvvetleri içerisinde bulunan Şah yanlısı bazı üst düzey elemanlar müdahaleyi abartarak Musaddık Hükümeti'ni korumayı deği adeta devirmeyi arzuladılar. Sekiz kamu binası göstericiler tarafından ateşe verilmiş, 300'e yakın sivil hayatını kaybetmişti. Saray'a bağlı askeri birlikler Musaddık'ın evini kuşatmışlar ve korumaları etkisiz hale getirmişlerdi. Musaddık kaçmışsa da daha sonra yakalanarak göz hapsine alınmıştı. Başarısız darbe girişiminden sonra kaçarak gizlenen General Zahidi gizlendiği yerden çıkarak tüm kontrolü ele aldı. ( New York Times, August 23, 1953, Kinzer, 2004: 218 )

16-22 Ağustos 1953 tarihleri arasındaki bir haftalık süre İran siyasal hayatındaki en dramatik olayların sığdığı bir dönem oldu. Önce parlamento feshedilerek Şahlık rejimine son verildi. Bu İran'da bir devrim gerçekleştiği anlamına geliyordu. Bu karar üzerine Şah Musaddık'ı azlederek yerine General Zahidi'yi getirdi. Musaddık'a bağlı güvenlik kuvvetleri bu kararı tanımayınca Zahidi Hükümeti göreve başlayamadan bitti. Ardından Musaddık'1 devirme operasyonu sonuçsuz kalınca Zahidi gizlendi Şah ise önce Bağdat'a sonra da Romaya kaçtı. Ancak Musaddık'ın lehine gösterilerin CIA tarafindan provoke edilmesiyle bu defa Musaddık karşıtı gösteriler ortaya çıkarıldı. Şah yanlısı ordu birliklerinin bu atmosferden yararlanarak bir darbe ile Musaddıkı devirmeleri Şah'ın 22 Ağustosta yeniden Tahrana dönerek koltuğuna oturmasının yolunu açtı. CIA in gücü bir gün önce Musaddıkı alkışlayan elleri ertesi gün Şah için havaya kaldırmaya yetmişti. ( Efimenco, 1955: 401-402, Richards, 1975: 4, Cottam, 1970: 13, Gasiorowski, 1987: 273 )

Şah CIA nın yardımıyla yeniden Sarayına dönünce aynı gün General Zahidi de Başbakanlık koltuğuna oturdu. Şimdi sıra Musaddık ve Milli Cephe'nin hiçbir şekilde geri adım atmadığı AIOC ile İran arasındaki anlaşmazlığın yeniden ele alınmasına gelmişti. Şah ve Zahidi sorunun çözümünü koltuklarını borçlu oldukları ABD' ne bıraktılar. Eylül 1953'de, ABD ve İngiltere arasında yapılan görüşmeler sonucunda, İngiltere'nin bazı itirazlarına rağmen İran petrollerinin işletilmesi yetkisinin bir şirketler konsorsiyumuna devredilmesine karar verildi. Buna göre, İran petrollerinin \%80'inin işletim hakkı eşit olarak ABD ve İngiltere petrol şirketlerine verildi. ( AIOC \% 40, 5 ABD Şirketi \% 40 ) Geriye kalan \% 20 oranın \% 14'ü Hollanda Şirketi Shell'e \% 6 sı da Fransız Petrol Şirketi'ne verildi. ( Armaoğlu, 1999: 491, Paine and Schoenberger, 1975: 26 ) Bir petrol şirketinin İran'dan kovulması ile başlayan süreç bütün Batılı petrol şirketlerinin İran'a girmesiyle sonuçlanmıştı. 


\section{0-Sonuç}

1953 İran Darbesinin, İran'ın siyasal hayatında günümüze kadar süren derin etkileri oldu. 1900'lü yılların başından itibaren İran'da emeklemeye başlayan demokrasi ve onunla kesintilere rağmen dönemsel olarak elde edilen tüm özgürlükler bu darbeden sonra bütünüyle sona erdirilmiş ve monarşik diktatörlük en geniş sınırlarına ulaşmıştır. ( Gasiorowski, 1987: 278 ) $\mathrm{Bu}$ dramatik sonucun en çarpıcı noktası da buna sebebiyet veren ülkelerin, dünyada demokrasinin iki öncü ülkesi olan, ABD ile İngiltere olmalarıdır. Soğuk Savaş Dönemi’nin başlarında Batı'nın stratejik bakımdan önemsediği ve Orta Doğu'nun güvenliği için hayati olarak gördüğü İran'daki çıkarları demokratik değerlerin önüne geçmiştir. Şah Muhammet Rıza Pehlevi'nin, 1954'den itibaren ABD ve İngiltere'den aldığ 1 destekle, ülkede uyguladığı bask1 politikaları her geçen gün halkın biraz daha nefretini kazanmıştır. Bu baskı mutedil İran halkını bir taraftan aşırı sol diğer taraftan da fanatik dini grupların kucağına atmıştır. Darbenin ortaya çıkardığı en önemli sonuçlardan birisi de İran Halkı'nın demokrasiye olan inancının zayıflaması olmuştur. Musaddık'ın son zamanlarda diktatörlük denemeleri içerisine girmesi kendisini destekleyen liberal gruplarda güvensizlik ve karamsarlığa yol açmıştır. Demokrasiye olan inancın zayıflaması darbeden sonra İran Halkının belki petrolden daha önemli bir kaybı olmuştur. Artık diktatör Şahla mücadele eden muhalefetin başında demokrasiye inancı olanlar değil, din adamları ve komünist gruplar yer almaya başlamışlardır. Bu açıdan 1979 İran İslâm Devrimi'nin tohumlarının 1953 darbesi ile ekildiğini söylemek mümkündür.

1953 darbesinin en önemli sonuçlarından biri de, İran Yönetimi ile değil ancak İran Halkı ile ABD'nin arasının tamiri neredeyse imkânsız şekilde açılmasıdır. Halbuki darbeden önce İran Halkının dünyada belki de en çok sempati duyduğu ülkelerin başında ABD gelmekteydi. İran II. Dünya Savaşı öncesinde birçok ülkenin baskısı altında kalmış bir ülkeydi. 1907 yılında İngiltere ile Çarlık Rusya'sı arasında ülkenin nüfuz alanlarına bölünmesi İran Halkının hafızasındaki canlılığını devamlı olarak koruyordu ve bu ülkelerin hiçbirine güveni yoktu. ABD’nin ise II. Dünya Savaşı sonuna kadar İran'la benzer bir ilişkisi olmamıştı. İran Halkı'nın gözünde $\mathrm{ABD}$, adeta dünyanın öbür tarafındaki kendisine zarar vermeyecek güçlü bir ülke idi. Özellikle II. Dünya Savaşı'ndan sonra Sovyetlerin İran'a yerleşme ve İran'1 bölme girişimlerinin ABD’nin desteği sayesinde sonuçsuz kalması halkın bu ülkeye duyduğu sempatiyi daha da artırmıştı. Milliyetçi Cephe bile İngiltere ve AIOC ile yaşanan kriz sırasında ABD'nin İran Halkı'nın yanında yer alacağına dair çok güçlü bir beklenti vardı. ABD'nin, başlangıçta bu beklentilere yakın durmasına rağmen, sonradan politikasını değiştirerek İngiltere'den yana tavır alması ve halk tarafından seçilen Musaddık Hükümeti’ni devirmesi İran Halkı ile ABD arasında kolay kapanmayacak bir yara açmıştır. İzleyen yıllarda, İran'da siyasetçiler Halkın bu ABD karşıtlığından fazlasıyla yararlanmışlardır. Humeyni'nin ABD'ni “ Büyük Şeytan “ olarak ilân etmesinde bu darbenin rolü önemli bir etkendir.

1953 darbesinin İran dış politikası üzerinde de etkileri oldu. Musaddık Hükümeti iktidarda kalsaydı büyük olasılıkla Batı Bloku'nun politikaları içerisinde yer almayacak belki Mısır örneğinde olduğu gibi Sovyetlere yakın duracaktı. Bu durumda Batı için kuzeyden de bir 
Orta Doğu'nun güvenlik sorunu belirecekti. Fakat Musaddık devrildikten sonra Şah ve yeni İran Hükümetleri kayıtsız şartsız Batı'nın bölgedeki politikalarına destek vermişlerdir. İran ABD’nin organize ettiği 1955 Bağdat Paktı'na tereddütsüz katıldığı gibi, ABD ile de bir yardım anlaşması imzalayarak Batı'nın bölgedeki en çok güvendiği ülkelerden biri olmuştur. Batı ile kurulan bu yakınlaşma birçok yabancı şirketin İran'la iş yapmasına ve çok sayıda İranlı öğrencilerin Batı Üniversiteleri ve özellikle ABD'de öğrenim görmelerine zemin hazırlamıştır. Bugün ABD Üniversitelerinde İran asıllı akademisyenlerin sayısının oldukça yüksek olmasında bu yakın ilişkilerin etkisi vardır.

1953 Darbesi'nin en dramatik sonuçlarından biri de, bu darbeye giden süreci yaratan aktörlerin her ikisinin de darbeden zararlı çıkmaları olmuştur. Kriz Milli Cephe Lideri Musaddık ile AIOC arasındaki petrol anlaşmazlığı ile başladı. AIOC başlangıçta İran'a dünya standartlarına uygun bir oran verseydi belki bu kriz çıkmayacaktı. Kriz çıktıktan sonra da her iki taraf geri adım atmamış karşılıklı çatışma da darbeye giden yolu açmıştı. Ancak darbede Musaddık devrilerek koltuğunu kaybederken AIOC nin de İran petrollerindeki işletim payı \% 40' a düşmüştür. Anlaşmazlığın başında İran'ın yarı yarıya ( \%50-\% 50 ) önerisini kabul etseydi bu kriz de yaşanmayabilir ve AIOC de daha az bir kayıpla bu işten çıkabilirdi. Bu açıdan 1953 darbesini uzlaşmanın yerine hırs ve çatışmaları koyanların dramatik bir şekilde birlikte kaybettiklerinin bir örneği olarak görmek mümkündür.

\section{REFERENCES}

- Abrahamian, Ervand, A History of Modern Iran, Camridge University Press, 2008.

- Armaoğlu, Fahir, 20. Yüzyıl Siyasi Tarihi, Cilt: 1-2 ( 1914-1995 ), Alkım Yay. İstanbul, 1999.

- Axworty, Michael, A History of Iran-Empire of The Mind, Basic Books,New York, 2008.

- Behrooz, Maziar, “ Tudeh Factionalism and the 1953 Coup in Iran “, International Journal of Middle East Studies, Vol. 33, No. 3 ( Aug., 2001 ), pp. 363- 382.

- Cottam, Richard. W, “ The United States, Iran and Cold War “, Iranian Studies, Vol 3, No.1, ( Winter, 1970 ), pp. 2-22.

- Efimenco, N.Marbury, “An Experiment With Civilian Dictatorship in Iran: The Case of Mohammed Mossadegh “, The Journal of Politics, Vol. 17, No. 3 ( Aug., 1955 ), pp. 390-406.

- Erkan, Süleyman, “ The Invasion of Iran by the Allies During World War II “, Codrul Cosminului, Vol. XVI, No. 2, ( Winter, 2010 ), pp. 109-132.

- Erkan, Süleyman, “ İran'a Yabancı Ülke Müdahaleleri 1907-1921 “, Akademik Orta Doğu, Cilt. 5, S. 1, 2010, ss 91-116.

- Gasiorowski, Mark J, “ The 1953 Coup D’atat in Iran “, International Journal of Middle East Studies, Vol. 19, No. 3 ( Aug., 1987 ), pp. 261-286.

- Ghods, Reza.M, “ The Rise and Fall of General Razmara “, Middle Eastern Studies, Vol. 29, No. 1 ( Jan. 1993 ), pp. 22-35. 
- Guardian.

- Halliday, Fred, “Tudeh: Conditions are More Favorable for Our Work ", MERIP Reports, No. 86, The Left Forces in Iran ( Mar.-Apr. 1980 ), pp. 17+20-21.

- Hamzavi, A.H, “ Iran and Tehran Conference “, International Affairs, 20, 2 ( Apr. 1944 ), pp. 192-203.

- Hess, Gary R, “ The Iranian Crisis of 1945-46 and Cold War “, Political Science Quarterly, Vol 89, No. 1, ( Mar. 1974), pp. 117-146.

- Katouzian, Homa, “ Nationalist Trends in Iran, 1921-1926 “, International Journal of Middle East Studies, Vol. 10, No. 4 ( Nov. 1979 ), pp. 419-443.

- Kinzer, Stephen, Şah'ın Bütün Adamları, Bir Amerikan Darbesi ve Orta Doğuda Terörün Kökenleri, Çev. Selim Önal, İletişim Yay., I. Baskı, İstanbul, 2004.

- Keddie, Nikki R, Modern Iran, Roots and Results of Revolution, Yale University Press, 2003.

- Lenczowski, George, “ United State's Support for Iran's Independence and Integrity, 1945-1959 “, Annals of the American Academy of Political and Social Science, Vol. 401, ( May. 1972), pp. 45-55.

- Luttwark, Edward, Coupd'Etat: A Practical Handbook, Harvard University Press, 1980.

- Majd, M.G, “ The 1951-53 Oil Nationalization Dispute and Iranian Economy: A Rejoinder “, Middle Eastern Studies, Vol. 31, No. 3 ( Jul., 1995 ), pp. 449-459.

- Marsh, Steve, “ The United States, Iran and Operation ' Ajax ' : Inverting Interpretative Orthodoxy “, Middle Eastern Studies, Vol. 39, No. 1 ( Jul., 2003 ), pp. $1-38$.

- Martin, Vanesa, “ Mudarris, Rebuplicanism and the Rise to Power Riza Khan, Serdar-1 Sipah “, British Journal of Middle Eastern Studies, Vol. 21, No. 2 ( 1994 ), pp. 199210.

- Milliyet.

- New York Times.

- Paine Chris, Erica Schoenberger, “ Iranian Nationalism and Great Powers: 1872-1954 “, MERIP Reports, Middle Eastern Research and Information Project, No. 37, ( May. 1975 ), pp. 3-28.

- Richards, Helmut, “ America’s Shah Shahansha’s Iran “, MERIP Reports, No. 40, ( Sep., 1975 ), pp. 3-22+24+26.

- Yazıc1, Tahsin, “Fidâiyan-1 İslâm “, TDV İslâm Ansiklopedisi, Cil: 13, s. 54.

- Wall Street Journal.

- Washington Post.

- Westwood, Andrew F., " Politics of Distrust in Iran “, Annals of the American Academy of Political and Social Science, Vol. 358, New Nations: The Problem of Political Development ( Mar., 1965 ), pp. 123-135. 